\title{
ENDOGENOUS PENSIONS AND RETIREMENT BEHAVIOR
}

\author{
RANDALL K. FILER \\ MARJORIE HONIG
}

CESIFO WORKING PAPER No. 1547

CATEgORY 1: Public Finance

SEPTEMBER 2005

An electronic version of the paper may be downloaded
- from the SSRN website: $\quad$ www.SSRN.com
- from the CESifo website: $\quad$ www.CESifo-group.de 


\title{
ENDOGENOUS PENSIONS AND RETIREMENT BEHAVIOR
}

\begin{abstract}
This paper suggests that pension characteristics are simultaneously determined along with workers' retirement ages. Both the age of pension eligibility and actual retirement age are determined by the productivity and marginal disutility of work, factors that are influenced by worker and job characteristics. This approach differs from previous studies of retirement that treat pensions as exogenous, implying that prior empirical work may have overestimated the responsiveness of retirement age to changes in pension structure, a possibility with obvious policy implications for efforts to raise the age of retirement. We find that, in the conventional single-equation framework, delaying the age of pension eligibility would significantly delay retirement. When treated in a recursive simultaneous system, however, age of pension eligibility retains no explanatory power.
\end{abstract}

JEL Code: J26, H31, H55.

Keywords: social security, early retirement, job characteristics, pension eligibility.

\author{
Randall K. Filer \\ Department of Economics \\ Hunter College/CUNY \\ Hunter West 1502 \\ 695 Park Avenue \\ USA - New York, NY 10021 \\ rfiler@hunter.cuny.edu
}

\author{
Marjorie Honig \\ Department of Economics \\ Hunter College/CUNY \\ Hunter West 1502 \\ 695 Park Avenue \\ USA - New York, NY 10021 \\ mhonig@hunter.cuny.edu
}

Randall K. Filer and Marjorie Honig are Professors of Economics at Hunter College and the Graduate Center of the City University of New York. Randall Filer is also Visiting Professor at CERGE-EI, a joint workplace of Charles University and the Academy of Sciences of the Czech Republic, Prague. Professor Honig is Co-Director of Research at the International Longevity Center. Professor Filer is a Research Fellow at CESifo, Munich, IZA, Bonn, The Manhattan Institute, New York, and the William Davidson Institute of the University of Michigan. We gratefully acknowledge research support from the National Science Foundation (SES-9111407) and the University Committee on Research Awards of CUNY. Computing resources were provided by the University Computer Center of CUNY. Thanks are due to Franco Pignataro, Tim Baker, Alex Dervis, and Jan Spitalski for assistance with this paper. We acknowledge useful comments on earlier drafts from seminar participants at Columbia University, Humboldt University, Berlin and CERGE-EI and appreciate advice on econometric issues from Bill Greene, James MacKinnon, Charles Manski, and Arthur Lewbel. A special debt of gratitude is owed to Jan Hanousek for solving estimation problems we thought were unsolvable. 


\section{Introduction}

The link between pensions and retirement behavior is of considerable interest to economists and, increasingly, to policymakers. The decline in the age of retirement in postwar years has generally been attributed in increased pension benefits, both private and through the Social Security system. ${ }^{1}$ A clear implication of these findings is that the anticipated difficulties in financing currently projected Social Security benefits could be mitigated by changes in the age of pension eligibility that could be expected to delay retirement.

This conclusion has been drawn from empirical work that has treated pensions as exogenous determinants of the retirement decision. With pension characteristics assumed to be exogenous, various researchers have reported substantial effects of changing the age of eligibility on retirement behavior. Woodland (1987) finds that eligibility for private pensions more than doubled the probability that a 64 year old worker with modal characteristics in his sample had retired. Stock and Wise (1990b) claim that shifting the age of first eligibility for pension (early retirement age) from 55 to 60 reduced the probability of retirement before age 60 by over a third, while Blau (1994) finds that the hazard of leaving the labor force at the age of eligibility was between 50 and 100\% higher than at surrounding ages.

We believe that the interpretations placed on these observed correlations may have been influenced by a fundamental misunderstanding of the link between pensions and retirement. In this paper, we test an alternative model that views pensions and retirement age as simultaneous outcomes of an

${ }^{1}$ For evidence on the effect of Social Security, see Quinn (1977), Boskin and Hurd (1978), Burkhauser (1979), Hanoch and Honig (1983), Burtless and Moffitt (1984), Hurd and Boskin (1984), Hausman and Wise (1985), Gustman and Steinmeier (1985), Honig and Reimers (1989), and Reimers and Honig (1996). For findings on the importance of employer pensions, see Burkhauser and Quinn (1983), Fields and Mitchell (1984), Kotlikoff and Wise (1987), Gustman and Steinmeier (1989), Stock and Wise (1990a, 1990b), Ippolito (1990), Lumsdaine, Stock and Wise (1992), Gustman, Mitchell and Steinmeier (1994), Thio and Woittiez (1996), and Blundell, Meghir and Smith (2002) . Other contributions to this literature are summarized in Honig and Hanoch (1981), Fields and Mitchell (1982), Lazear (1986), and Quinn, Burkhauser and Myers (1990). 
underlying comparison of workers' productivity and their disutility from work. By misstating the relationship between pensions and retirement, previous studies may have substantially overstated the potential for using changes in pensions to alter retirement behavior. ${ }^{2}$ This potential bias is of more than theoretical interest since interpreting the observed correlation between pensions and retirement age as causally driven would induce firms to underestimate the change in pension wealth required to create a desired change in retirement age.

A weaker than expected response of retirement age to pensions could also have implications for public policy. The 1983 Amendments to the Social Security Act included incentives to delay retirement beyond age 65 . The age of eligibility for full benefits was to gradually be increased from 65 to 67 during the years 2003 to 2027, effectively reducing benefits of those retiring before age 67. Further delays are currently under consideration. Projections of the impact of these delays in the age of eligibility on actual retirement age play a key role in the anticipated role that changes in Social Security provisions will play in the financial soundness of the system. To the extent that retirement age is embedded in a long-term optimizing decision, however, it may prove to be less responsive to changes in either private or public pensions than cross section research suggests. ${ }^{3}$ As a consequence, neither expected increases in payroll tax revenue nor expected reductions in outlays for Social Security benefits will be fully realized. In this case, the Social Security trust funds may come under renewed pressure as workers adapt private savings to maintain the optimal age of retirement. Other countries face similar problems in redesigning pension

${ }^{2}$ Some researchers have been aware of this possibility but have ignored it in empirical work (See, for example, Fields and Mitchell,1984, and Ippolito,1990). To our knowledge, only the study by Thio and Woittiez (1996) has treated the age of eligibility for employer pension benefits as an endogenous variable.

${ }^{3}$ This interpretation is consistent with results in Chan and Stevens (2004), which show that withinperson variation in retirement incentives have less than half the impact on retirement age that would be predicted from cross-section analyses. See also Coile and Gruber (2000), who raise a concerns about the "lack of careful attention to the sources of identification of retirement incentives (p. 9), especially with respect to the correlation of wages and pension wealth with individuals' underlying tastes for retirement. In our framework these tastes for retirement will arise from differences in occupational characteristics as well as personal preferences. 
systems in the face of fiscal pressures and may be in danger of basing policy on similarly problematic results from estimates assuming that pensions are exogenous. ${ }^{4}$

It should be noted that nothing in our analysis is inconsistent with empirical findings that sudden, unanticipated discontinuous changes in pension terms such as early retirement bonus windows induce large responses (see Mutschler (1986) and Brown (1996)). Obviously, the ability of individuals to adust private savings to offset changes in pension plans will increase the longer they have to adapt. If an individual who has optimally planned on retiring at a given age and saved accordingly is presented with a large increase in wealth conditional on retiring at a slightly earlier age, it is to be expected that this wealth effect may induce a retirement response. Thus, a change in age of eligibility that occurs near the optimal age (when the bulk of savings have taken place) will have a very different result than one that occurs early in a worker's life when there is sufficient time for savings to adapt. This implies that responses to policy changes should be expected to decay over time.

In this paper, we test the endogeneity of pensions in the retirement process. We estimate a model that treats pensions and retirement age as joint outcomes resulting from workers and firms comparing productivities and reservation wages (disutility from working an additional period) at various ages. Estimates are derived from a data set that contains job characteristics accumulated from a number of sources merged with longitudinal micro-data from the Retirement History Survey (RHS) of the Social Security Administration. Findings generally support the contentions that the age of pension eligibility is endogenously determined along with the age of retirement, and that the failure to recognize this relationship may impart a substantial upward bias into estimates of the effect of pension eligibility on the decision to retire.

${ }^{4}$ See Siddiqui (1997) for an example of such a policy analysis that devotes a great deal of attention to specifying pension benefits properly for any given worker but still assumes that the terms under which these benefits are set are exogenous to that worker. 


\section{Employer Pensions and the Retirement Decision}

Private pensions are an important source of retirement income and comprise a large share of individual wealth in many developed economies. In 2003, pension fund assets amounted to 69\% of GDP in the U.S. Comparable figures in other economies were even higher (ranging up to 101\% of GDP in Switzerland and 106\% of GDP in the Netherlands). In order to understand how such pensions might affect retirement behavior, we begin by considering a world in which pensions do not exist. As a worker ages both his or her productivity and the disutility resulting from working another period will change. In a true spot labor market, where wages are always equal to the value of marginal product, retirement will be optimal whenever the additional income (productivity) from working the next period falls below the disutility generated by working that period. It is reasonable to assume that the disutility from, and the productivity of, working an additional period will change at different rates in different jobs depending on the characteristics of those jobs. They will also, obviously, vary across individuals according to the characteristics of the workers. Thus, the age at which workers retire will depend on both the characteristics of the workers and of the jobs they hold. In a true spot labor market, firms, which always pay workers the value of their additional output in each period, will be indifferent to the age at which retirement occurred.

In such a world there is no need for pensions. Workers who anticipated retiring ${ }^{5}$ would simply save during their working life to finance post-retirement consumption. The most obvious reason for pensions is their tax advantages, with pension contributions being allowed to accumulate pre-tax until after the worker retires. Pensions in such a world, however, should be defined contribution plans in which a specified portion of earnings are set aside each period as a contribution to a pension. Such plans could utilize tax advantages and force workers to make a binding pre-commitment to save for retirement, yet

${ }^{5}$ Not all workers need to plan for retirement. It is easy to envision occupational-worker matches where productivity never falls below the disutility from work, so that workers might expect to continue to work (perhaps with reduced hours) until death. 
easily maintain the equality between wages (including pension contributions) and productivity in each period. A large (although decreasing) number of pension plans, however, are not defined contribution plans but rather defined benefit plans that provide a specific benefit after retirement and adjust contributions to ensure that the amount set aside is sufficient to finance this benefit. ${ }^{6}$

Defined benefit plans must, therefore, exist for reasons other than tax-advantaged savings. One possibility is that such plans have the advantage of shifting capital market risk from workers to firms who can, for all the usual portfolio reasons, be assumed to be the less risk-averse participant in the employment relationship. A more compelling rationale arises from the role of pensions in optimal contracts. A number of models suggest that both firms and workers benefit from a payment stream in which workers receive less than the value of their marginal product when young and more than their marginal product when old. Lazear (1979) suggests that such a profile reduces workers' incentives for shirking and cheating and thereby raises their lifetime wealth. Other long-term contract models focus on the role of pensions in retaining workers with firm-specific human capital (Becker, 1962) and in sorting workers according to unobservable characteristics (Salop and Salop, 1976).

Even if wages ${ }^{7}$ diverge from the value of a worker's marginal product in each period, however, competition in the labor market ensures that the present discounted value of wages and productivity must be equal over the worker's entire career:

${ }^{6}$ This remains true even though defined contribution plans have become increasingly popular in recent years, particularly with the introduction of voluntary employee-contributed 401(k) plans. Among small firms, 401(k) plans tend to serve as the primary pension plan, Among medium and large firms, however, the incidence of defined benefit and defined contribution plans is about equal at $50 \%$ of workers. Data from IRS filings indicates that, among firms with more than 100 employees, the proportion of workers whose primary plan provided defined benefits was 80 percent in 1985 (Clark, Gohmann, and McDermed, 1988).

${ }^{7}$ Where wages are defined to include increases in pension wealth in any period. 


$$
\sum_{t=0}^{R} w_{t} \frac{1}{(1+r)^{t}}=\sum_{t=0}^{R} V M P_{t} \frac{1}{(1+r)^{t}}
$$

where $\mathrm{r}$ is the interest rate, VMP is the value of the worker's marginal product, and $R$ is the age of retirement.

Obviously this equality can not be set to hold with $w \neq V M P$ for each period unless $R$ is known. However, for these purposes any $R$ will suffice and, once $R$ is known, an appropriate wage profile can be set. The question that we must address is how $R$ is determined. As in the optimal separations literature (see Mortensen, 1978; Hashimoto and Yu, 1980; and Hashimoto, 1981), it is optimal from both sides of the market (employer and employee) for a worker to leave a firm whenever productivity in that firm falls below outside opportunities. The retirement decision can simply be viewed as a special case of this world where the alternative is the reservation wage instead of the productivity in another firm. Thus, ex ante, at the time of initial contracting both workers and firms will want to set $\mathrm{R}$ at exactly the age at which productivity falls below the disutility from work.

Ex post, however, long-term contracts will result in the actual wage being higher than productivity at this age. Workers will, therefore, have an incentive to renege on the initial contract and continue working until the disutility from work has risen enough to equal $w$ (where it is, by definition, > VMP). Thus, some enforcement mechanism must ensure that workers retire when initially planned. The easiest such enforcement mechanism is to establish a firm-specific age of mandatory retirement at an age that reflects the distribution of optimal retirement ages among the firm's workers. If, however, this cannot be done, an acceptable second best is to provide a financial incentive to retire at this age. This can be done by buy-out offers or by discontinuous changes in the amount of pension wealth. Alternatively, if workers are myopic (see Reimers and Honig, 1996), simply making benefits available only after a given age will be perceived as a discontinuous increase in the value of retirement at that age. 
Thus, we would expect to find large changes in pension wealth corresponding with the age at which workers are eligible to retire. In most defined benefit plans, the increase in pension wealth is largest at the age at which workers are first eligible for benefits, even though full benefits may not be paid until the "normal” retirement age. Surveying a sample of plans covering 530 workers, Gustman and Steinmeier (1989) found that pension wealth increased by 15 to 16 percent of annual wages in each of the several years immediately before and after the age at which a worker was first eligible for benefits but by almost 75 percent of annual wages in the first year of eligibility. ${ }^{8}$

We would also expect to find that worker and job characteristics determine both the structure of the long-term contract, including its pension provisions, and the age at which workers retire. This emphasis on the endogeneity of pension characteristics in response to the work environment in the theoretical literature stands in stark contrast to the widespread assumption of exogeneity in empirical work. Lazear (1979) finds evidence that workers' education, for example, is positively correlated with firms' age of mandatory retirement (and thus with pension eligibility).

Job characteristics have also received attention. Studies that have examined their role in influencing retirement age include Quinn, 1978; Gustman and Steinmeier, 1986; Filer and Petri, 1988; Holden, 1988; Hayward et. al., 1989; Chirikos and Nestle, 1991; Hurd and McGarry, 1994; Thio and

\footnotetext{
${ }^{8}$ See also Kotlikoff and Wise (1987). Gustman and Steinmeier also report a much smaller spike in the increase in pension wealth (24\% of annual salary) at the age of eligibility for full benefits as well as a decrease in pension wealth for each year worked after "normal" retirement age, since most plans did not accrue years of service into benefit formulae after this age. This lack of accrual is no longer legal in the U.S., so it is an open question whether the small spike at the stated age of normal retirement remains in existence. We are relatively agnostic as to why firms maintained this second, smaller spike. It may have arisen because of integration with the Social Security system (most firms initially defined the age of normal retirement at 65 , the age of eligibility for full Social Security benefits). An economic rationale for its existence may arise if firms want to use an unusually large wage increase to bribe workers who have been revealed to be especially productive after the initial contract provisions are determined to continue working past the age of anticipated retirement. In this case, a second spike at a later age will be required to induce these workers to leave the workforce. It remains the case, however, that the frequent occurrence of a large increase in pension wealth at the age of eligibility for early retirement strongly suggests that this is the age at which firms and workers anticipated inducing retirement at the time the contract was designed.
} 
Woittiez, 1996; Solem and Mykletun, 1997; Hayward, Friedman and Chen, 1998; Hirsch, Macpherson and Hardy, 2000; Yeatts, Folts, and Knapp, 2000; Derriennic, Saurel-Cubizolles and Montfort, 2003; Johnson, 2004; and Blekesaune and Solem, 2005). All except the studies by Filer and Petri and Thio and Woittiez, however, have ignored the potential effect of job characteristics on pension characteristics.

If, as workers age, there are differential changes in productivities and in tolerances for various job conditions, then the expected length of a worker's career and the provisions of his or her optimal contract should differ from job to job. When a job's characteristics point to a relatively short work-life (i.e., "early retirement"), pension plans should provide for early receipt of benefits. From this perspective, job characteristics should influence both pension structure and retirement age, and the observed relationship between pensions and retirement age in the empirical literature should be recognized as one of correlation, not causation. ${ }^{9}$ In the extreme the logic of this reasoning is obvious. The fact that their pension plan allows retirement in after less than 20 years of service is unlikely to be the reason that most professional football players retire before the age of 40 . On the other hand, given that the demands of professional sports mean that few athletes are able to perform at the required level as they approach middle age does provide a strong incentive for professional sports unions to negotiate contracts that allow for retirement at an early age. The same reasoning goes for strenuous but less visible jobs such a police and fire services where retirement after 20 years (typically before individuals reach age 50) is a common contract provision.

Evidence supporting the role of worker and job characteristics in influencing pensions comes from examining the age at which workers are eligible for benefits across various plans. Overall, the age of

${ }^{9}$ One implication of this approach is that desired changes in retirement age are more likely to be created by changes in job attributes than by changes in pension wealth or structure. For example, jobs imposing heavy physical demands that induce early retirement might be restructured as multiple part-time positions or might be redesigned to increase the amount of labor-saving capital employed. Similarly, some of the more stressful aspects of jobs might be reduced by appropriate redesign. Job redesign as a tool for affecting workers' retirement decisions has generally been ignored in the literature. Doeringer and Terkla (1989), however, discuss attempts by employers faced with labor shortages to retain older workers. To the extent that job design is negotiated at the time of hire, job characteristics, as well as age of eligibility, may be endogenous. Relative to the latter, however, job characteristics are likely to be technologically determined to a greater extent and thus less open to negotiation. 
eligibility has fallen in recent years. In 1960, none of the conventional defined benefit plans included in a survey of 350 large firms paid full pension benefits prior to age $65 .{ }^{10}$ By 1980 , 69 percent of the plans surveyed provided full benefits earlier than age 65. Over the same period, the mean age at which workers were eligible to first receive actuarially-reduced early benefits declined from 56.7 to 53.9 years. ${ }^{11}$ The key observation, however, is that despite the substantial reduction in the mean age of first eligibility for pension benefits, the variance in this age across plans remained remarkably stable. In 1960, 5 percent of conventional defined benefit plans provided early benefits as early as age 50, 56 percent at age 55, and 31 percent at age $60 .^{12}$ The distribution of ages of eligibility for early benefits twenty years later represents to a first approximation simply a leftward shift of this earlier distribution. In 1980, 24 percent of plans provided early benefits at age 50, 67 percent at 55, and 4 percent at $60 .{ }^{13}$ Thus, while the mean age of eligibility for benefits declined by 2.8 years during this period, the coefficient of variation of the age of

\footnotetext{
${ }^{10}$ Bankers Trust, 1980. This survey, by one of the largest custodial banks for pension plans in the U.S., was conducted every five years from 1960 to 1980. Firms included in the survey employed approximately $25 \%$ of all pension plan participants. "Conventional" plans normally use both years of service and last earnings in determining benefits; less common "pattern" plans use years of service only (See Ippolito, 1990, for a detailed discussion of these data). "Full" benefits are computed by applying the normal retirement benefit formula to the compensation and years of service up to the date of retirement without any reduction for earlier receipt of the pension.
}

${ }^{11}$ There are a number of reasons why ages of eligibility may have fallen over this period. With the workweek having stabilized at around 40 hours, increases in leisure consumption in response to rising real incomes appear to have come in the form of greater contiguous blocks of non-work time such as longer vacations and earlier retirement. Firms and workers may also have responded to changes in Social Security over this period that made earlier retirement more attractive. Reduced Social Security benefits at age 62 first became available to men in 1961 (women had been eligible for reduced benefits at that age since 1956). This change would have caused a discontinuous shift upward in the reservation wage at age 62, similar to that created by eligibility for full benefits at 65, and may have lowered the optimal retirement age for some workers. In addition, the real value of Social Security benefits increased substantially during the early 1970s. Finally, intertemporal substitution considerations may have made it optimal for generations reaching their sixties in the 1980s to concentrate their working hours earlier in their life and concentrate their consumption of leisure in their older years when labor market competition from the baby boom generation put downward pressure on real wages.

${ }^{12}$ Of the remainder, 4 percent did not provide for retirement before eligibility for full benefits and 4 percent had a service requirement only (Bankers Trust, 1980, Appendix Table 17).

${ }^{13}$ The remaining 5 percent did not use age as a criterion for eligibility (Bankers Trust, 1980). 
first eligibility remained roughly constant at .05. We suggest that this stability in the variance of the age of eligibility for early benefits, during a period of substantial change in other aspects of defined benefit pension plans, is indicative of fundamental and persistent differences across firms in the optimal retirement age.

A similar variability in ages of eligibility exists in other countries. In 1991, 5\% of British men between the ages of 45 and 54 were receiving an employer-sponsored pension as opposed to $19 \%$ of those 55 to $59,40 \%$ of those 60 to 64 and $70 \%$ of those over 65 years of age (OECD, 1997).

We further observe that systematic differences in the age of eligibility for early benefits appear to exist across industries, strengthening our contention that pensions are related to worker preferences and job characteristics. Provision for retirement at the earliest reported age of 50 was far more common in 1980 in heavy-manufacturing industries such as chemicals (42\% of plans), utilities (30\%), oil (29\%), and pharmaceuticals (27\%), for example, than it was in retail trade and food (0\%), insurance (8\%), or banking (11\%). ${ }^{14}$ We also observe substantial variation in retirement age across occupations during the same period. As shown in Table 1, the mean age of those retiring from different occupations during the second half of the 1970s ranged from the late 50s to over 70.

These differences in defined benefit pensions and in retirement ages cannot be accounted for in conventional models that treat pensions as exogenous to the retirement process. They are consistent, however, with the premise that worker and job characteristics influence both the age of pension eligibility and the age of retirement. A model outlining this relationship is described in the next section.

\section{The Dynamics of Retirement Behavior}

The estimations presented below can be motivated by a simple model of retirement behavior and pension plans. The basic results are derived from three assumptions:

\footnotetext{
${ }^{14}$ Bankers Trust (1980).
} 
1) As workers age, both their productivities in their jobs and their reservation wages (marginal disutilities) for working an additional period in these jobs change. In general, their marginal disutility from work will increase and their marginal productivity will fall (or at least not increase as rapidly as the disutility).

2) Both workers and firms will want to provide for retirement at the age at which the productivity from working an additional period falls below the disutility from working that additional period. Because of long-term contract considerations, actual wages at this age may be greater than productivity. Thus, contracts will be designed and agreed to by both parties at the time of initial employment to either require firms to fire workers at this age (mandatory retirement) or induce workers to retire at the optimal age.

3) The optimal age of retirement can, therefore, be inferred by examining the provisions built into pension plans. The most common method of creating incentives that induce retirement at the ex ante optimal age is to provide a discontinuous increase in workers' pension wealth at this optimal age. We have presented evidence of unusually large increases in pension wealth at particular ages. The fact that pension wealth increases so much at a particular age suggests that, given information costs, workers may obtain all the information they need about the provisions of their pension plans by knowing at what age they are eligible to retire rather than the full benefit calculation rules. The practical import of this assumption is that the key elements of pension plans can be summarized by the use of age of eligibility rather than more complicated variables such as pension wealth accruals at each age. ${ }^{15}$

${ }^{15}$ There is a good deal of evidence that workers do not in fact know their pension wealth until just before they actually retire (see, for example, Reimers, 1977). The above analysis suggests that this may not be as irrational as it first appears. Workers whose pension structure is set in response to their optimal age of retirement need only to know that age. 
If all contracts were worker-specific and everything were known with certainty at the time the contract was written, then age of eligibility and age of retirement would always be identical and either could be estimated as a reduced-form function of worker and job characteristics. Given the presence of uncertainty, a distribution of both productivities and reservation wages, and common pension plans that cover workers with different characteristics in different occupations, observed ages of eligibility and of retirement are linked but not identical. In particular, two fundamental relationships exist:

$$
A_{e}=f(X, Y)
$$

and

$$
A_{r}=g\left(X, Z, A_{e}\right)
$$

where $A_{r}$ is the worker's actual age of retirement and $A_{e}$ is the age at which the worker is eligible for pension benefits. $X$ is a vector of characteristics that determine both age of retirement and the age at which a worker's contract provides for pension benefits. Our model suggests that this vector is composed of characteristics that determine both worker productivity and disutility from work, i.e., characteristics of the job and attributes of the individual at the time of job acceptance. The latter category might include age, education, and expected lifetime income. Furthermore, the model suggests that if workers perfectly predict their future preferences and opportunities, $f_{x}$ and $g_{x}$ should have the same sign . $Y$ and $Z$ represent the vectors of variables that determine only age of pension eligibility and actual age of retirement, respectively.

Previous work has typically estimated only Equation (2) above. In doing so, it has explicitly assumed $A_{e}$ to be exogenously determined, as discussed above. It has also typically omitted worker attributes and job characteristics in the $X$ vector from the equation. This creates two possible estimation problems. There is a classic case of bias due to the presence of an endogenous right-hand side variable, with age of eligibility being correlated with the error term in the age of retirement equation. There may also be an omitted variable problem created by the omission of job characteristics from the age of retirement equation since the existence of equation (1) implies that $\operatorname{cov}\left(A_{e}, X\right)$ will not be zero. This 
suggests that conventional estimates are likely to overstate the true effect of exogenous variations in $A_{e}$ on retirement behavior by incorporating into estimated eligibility effects the influence of variables that determine both ages of eligibility and retirement. We investigate each of these potential problems. Results will be reported first for estimates that allow the age of pension eligibility to be endogenous, ignoring the potential effect of job characteristics. We then report the impact of including these characteristics.

\section{Data}

The model outlined above is estimated using a sample drawn from the Retirement History Study (RHS) of white married men on career jobs in 1969 who were observed to retire from these jobs during the 11-year span of the survey. This sample has been the basis for a number of studies of retirement and labor market re-entry behavior (Honig and Reimers, 1987, 1989; Reimers and Honig, 1993, 1996). The disadvantage of using the RHS is that while it includes information on age of pension eligibility, it does not include pension benefit formulae; thus we are unable to calculate the actual increase in pension wealth at each age. We have argued above, however, that the important factor for our model, the age at which pension contracts expect workers to require, is revealed by the age at which they are eligible to retire, a conclusion supported by the fact that workers typically know the latter but not their pension wealth. The advantage of using the RHS is that it contains longitudinal data for a large sample at a time when defined benefit plans, where age of eligibility is a meaningful concept, predominated in the U.S. Due to the lack of variation in public pension ages of eligibility, it is typically cross-section variation in the terms of such plans that forms the basis of projections regarding the impact of changes in public pensions. We focus on analysis of the two interrelated variables in these data, according to the model outlined above: the age at which a worker is first eligible for a pension ${ }^{16}$ and the age at which he actually retires.

${ }^{16}$ Age of early retirement if such is available in the pension plan and age of full retirement if there is no provision for early retirement. 
Among 2,541 white married male wage-earners for whom employment histories could be constructed, 1,652 were on career jobs in 1969. Career jobs are defined in this sample as full-time (30 or more weekly hours of work) jobs held since before age 55, providing the worker does not describe himself as either partially or fully retired. ${ }^{17}$ Of these workers, 1,253 were observed to leave these jobs during the survey, 712 of whom were covered by pensions and also reported the industry and occupation of their job. ${ }^{18}$

We further limited the sample to those aged 58-60 at the start of the survey, resulting in a final sample of 453 career job-holders in 1969. By restricting the sample to a narrow age range of relatively younger workers, we reduce the effects of unmeasured tastes for work on retirement age. If we had included workers older than age 60 (the earliest age at which significant retirement is observed in the full

\footnotetext{
${ }^{17}$ Most remaining workers were on jobs they had recently begun, for which the concept of retirement is less clear. See Appendix Table A-1 for construction of the sample used in earlier studies and additional exclusions relevant to the current study.

${ }^{16} \mathrm{~A}$ total of 396 workers on full-time career jobs in 1969 were excluded in the original sample because a transition to retirement was not observed for them. Of these, 96 moved directly to a new employer after leaving their career job, 53 moved to part-time status with the same employer, and 247 either left the survey or were still working at the last interview in 1979. We were not able to determine how many workers among the 53 moving to part-time status were still employed by their career employer at the 1979 interview, nor how many among the 247 career job holders were still working at the last interview, as opposed to having left the sample due to death or simple attrition. Our results therefore may be biased due to this rightcensoring. (Of the 96 moving directly to another employer, only those receiving pension benefits from the career employer would have been included in our sample of retired workers.) We believe the magnitude of the bias to be fairly small, however. Among white men in the RHS survey as a whole, only 11.9 percent were working in 1979. Even in the extreme case that all 300 career job holders omitted in the original sample were still working in the 1979 interview, only a small proportion were likely to have been covered by a private pension. In 1979, only 15 percent of white male wage earners aged 65 and over were covered by pensions (Kotlikoff and Smith 1983, Table 3.2.5). This proportion is likely to be an over-estimate for the workers of concern, who would have been 68 and over in 1979. Nonetheless, if we estimate that 15 percent, or 45 , of the 300 workers were covered by pensions, it is likely that one-fifth to one-quarter of these would not have reported the industry and occupation of their career job (using sample proportions for workers observed to retire before the last interview (Appendix Table A-1). Finally, only two-thirds of those remaining are likely to have been in the selected age range, 68-70, in 1979 (see Appendix Table A-1, and discussion below). Thus, we estimate that our final sample would have been larger by about 5 percent, or approximately 25 workers.
} 
RHS sample), those with especially strong distastes for work may have already retired, resulting in a nonzero mean of the distribution of error terms.

Table 2 provides a cross tabulation of the distributions of the two dependent variables in our model: the earliest age of eligibility (for reduced benefits, or for full benefits when reduced benefits are not offered) and the age of retirement. It is clear that while ages 62 and 65 are the modal ages for earliest receipt of benefits, $11.8 \%$ of the sample are eligible before 62, with ages 55 and 60 being most frequent. Less than $2 \%$ of the sample are first eligible for benefits after 65 . Similarly, there are peaks in actual retirement at ages 62 and 65, but 23.6\% of the sample retire between these modal ages. Slightly under 13\% retire earlier than age 62 . Finally, careful inspection of the table indicates that age of eligibility and age of retirement are related.

The RHS does not contain information regarding the characteristics of jobs held by panel members. It does, however, indicate the industry and occupation of employment at the three-digit level, enabling the inclusion of job characteristics from other sources. In the end, five job characteristics were included in the analysis covering a wide range of characteristics that intuitively ought to be related to optimal ages of retirement and pension eligibility. They are:

(1) Whether it is a worker's own responsibility to decide how things get done on his job.

(2) How hard it would be for workers to get the duties of their job changed if they wanted to.

(3) Whether a worker is exposed to any "great or sizable" hazards in the workplace.

(4) Whether physical conditions at the workplace are not as pleasant or comfortable as workers would like.

(5) How much effort (either physical or mental) the job requires. ${ }^{19}$

Other right-hand-side variables in the equations estimating both the age of pension eligibility and the realized retirement age are those in the $\mathrm{X}$ vector that measure attributes of the individual. These

${ }^{19}$ For a discussion of the process by which these characteristics were chosen, see the discussion in Filer and Honig, 2005. 
include the worker's years of education, ${ }^{20}$ whether the job was in the government sector (where pension incentives may be different than in profit maximizing .firms), a proxy measure for the worker's expected permanent income, ${ }^{21}$ the worker's health status, ${ }^{22}$ and the age at which he started his career job. The age of eligibility equation also includes as variables in the $Y$ vector the macroeconomic variables at the time the worker started his career job. The age of retirement equations also include variables in the $Z$ vector. These are attributes of the individual at the time of retirement such as whether the worker was still married (a small proportion of the sample experienced changes in marital status after 1969), whether he resided in a warm region, and the macroeconomic conditions at the time of retirement. With the exception of residence, these variables are included only in the age of retirement equation because they should have been largely unknown to workers at the time pension terms were chosen. Residence in warm regions is assumed to affect only the realized retirement age due to the national nature of most pension plans.

\section{Estimation}

\section{A) Functional Form}

Inspection of Table 2 indicates that there are concentrations of retirement at certain ages, particularly at 62 and 65 . This suggests that linear models may be inappropriate specifications for the problem under study. If the "heaping" at certain ages results from factors that are not captured in the variables used for estimation (such as the structure of the Social Security system), the result will be nonnormality in the error distribution. An obvious way to rectify this situation is to estimate an ordered

\footnotetext{
${ }^{20}$ Since about $10 \%$ of respondents did not report their education, they were included with a value of zero along with a dummy variable for education being missing.

${ }^{21}$ Calculated as the sum of real earnings between ages 45 and 58 . Since the earnings were taken from Social Security records, amounts were annualized if the taxable earnings maximum was reached in the third quarter or earlier.

${ }^{22}$ Health status is measured at the end of the worker's career job since health status at the start of the current job is not available in the RHS.
} 
categorical model such as an ordered probit or ordered logit model. In such a model, the threshold values between the categories can be fitted so as to account for the varying density of retirements at different ages. Fields and Mitchell (1984), for example, have estimated an ordered logit model of age of retirement.

Estimation is complicated by the simultaneous nature of the system under study. There is a limited literature dealing with bivariate ordered categorical models. Lee (1982), Uesaka (1986), and Poon et. al. (1987) provide theoretical bases for such models. The models to date, however, have been simultaneous only in the sense that they accommodated correlations across the error terms in two ordered categorical equations or use ordered probit models as the first stage of a selection bias model. ${ }^{23}$ None, to our knowledge, has allowed an endogenous right-hand-side variable in one of the estimated equations.

The likelihood function for such a model is, however, straightforward. Suppose the two underlying equations are:

$$
Z_{t 1}=X_{t 1} \beta_{1}+\epsilon_{t 1} \quad \text { where } \epsilon_{t 1} \sim n\left(0, \sigma_{1}^{2}\right)
$$

and

$$
Z_{t 2}=X_{t 2} \beta_{2}+\gamma\left(X_{t 1} \beta_{1}\right)+\left(\gamma \epsilon_{t 1}+\epsilon_{t 2}\right) \quad \text { where } \epsilon_{t 2} \sim n\left(0, \sigma_{2}^{2}\right)
$$

For notational simplicity, the compound error term can be rewritten as:

$$
\psi_{t} \text { where } \psi_{t} \sim n\left(0, \gamma^{2} \sigma_{1}^{2}+2 \gamma \sigma_{12}+\sigma_{2}^{2}\right) \text {. }
$$

The observed categorical variables, $Y_{t 1}$ and $Y_{t 2}$, take on values " $j "$ and " $k$ " according to the rules:

$$
Y_{t 1}=j \Leftrightarrow \mu_{j-1}<Z_{t 1} \leq \mu_{j}
$$

and

$$
Y_{t 2}=k \Leftrightarrow v_{k-1}<Z_{t 2} \leq v_{k}
$$

Then, if $\rho$ is the covariance between $\epsilon_{t 1}$ and $\psi_{t}$, and $\Phi_{2}$ is the bivariate normal cumulative density function, the likelihood function becomes:

$$
\log L=\sum_{t=1}^{T} \log Q_{y_{1} y_{2 t}}
$$
(1997).

${ }^{23}$ For an application, see Moon and Stotsky (1993) and for a general discussion Butler and Chatterjee 
where the cell probabilities are defined as:

$$
\begin{aligned}
Q_{y_{1} y_{2 t}} & =Q_{j k}=\Phi_{2}\left(\mu_{j}-X_{1 t} \beta_{1}, v_{k}-\gamma X_{1 t} \beta_{1}-X_{2 t} \beta_{2}, \rho\right) \\
& -\Phi_{2}\left(\mu_{j-1}-X_{1 t} \beta_{1}, v_{k}-\gamma X_{1 t} \beta_{1}-X_{2 t} \beta_{2}, \rho\right) \\
& -\Phi_{2}\left(\mu_{j}-X_{1 t} \beta_{1}, v_{k-1}-\gamma X_{1 t} \beta_{1}-X_{2 t} \beta_{2}, \rho\right) \\
& +\Phi_{2}\left(\mu_{j-1}-X_{1 t} \beta_{1}, v_{k-1}-\gamma X_{1 t} \beta_{1}-X_{2 t} \beta_{2}, \rho\right) .
\end{aligned}
$$

\section{B) Results}

Table 3 contains results of our analysis treating the age of pension eligibility as endogenous and including job characteristics among the explanatory variables. The first two columns present a singleequation ordered probit estimates where the age of pension eligibility is assumed to be exogenous. Consistent with the results from previous studies, a worker's age of pension eligibility appears to play a highly significant role in determining the age at which that worker will retire. For example, evaluated at the sample means, the probability that a worker who is eligible for a pension at age 62 will retire before age 65 is .70 as opposed to a .30 probability that he will retire at age 65 or above. Increasing this worker's age of eligibility to 65 reduces the probability he will retire before age 65 to .58 .

Other variables in the single-equation model generally behave well. More educated workers retire later, perhaps reflecting a desire to recoup investments over a longer period or the types of jobs that are typically held by educated workers. Government workers are eligible for pensions at an earlier age, but conditional on the eligibility do not actually retire earlier than other workers. A similar pattern is seen with respect to a worker's permanent income, where higher-income workers opt for earlier pension eligibility but, conditional on that eligibility, do not retire earlier than other workers. Workers with health limitations at the time they retire do retire earlier but are not differentially found in jobs with earlier pension eligibility, a result consistent with health limitations arising after entering their career job. The later a worker starts his career job, the later he is eligible for a pension, reflecting both years of service 
rules common in many pension plans and the fact that workers will be more likely to change employers late in their working lives if they anticipate retiring at a later age, thereby giving themselves more years to recoup mobility costs. This effect seems to be fully captured in pension characteristics and, conditional on the age of pension eligibility, there is no effect of starting age on actual age of retirement. Finally, residents of warm regions retire later, perhaps because those in colder regions have an incentive to retire in order to be able to move to more pleasant climates.

Interpretation of the macroeconomic conditions (inflation rates and unemployment rates) used as an aid in identification, is less straightforward. They are clearly important in determining actual age of retirement, with both higher inflation and greater unemployment at the end of a worker's career leading the worker to delay retirement. There are logical reasons why marginal increases in each of these factors might delay retirement. To the extent that it is unanticipated, higher inflation reduces the real value of workers' assets, resulting in an income effect that ought to delay the consumption of greater leisure. If workers are expecting to take a post-retirement job (even on a part-time basis), a slack labor market (reflected in higher unemployment) may make such jobs harder to find, leading workers to remain on their career jobs longer. Since we start with a sample of fixed age in 1969, however, if either of these variables trended upwards over the period for which we follow workers, there will be a degree of spurious correlation as well. Unemployment was relatively stable for the first six years of our panel, but did increase in 1975-76 when a few older workers in the sample were still retiring. Thus there may be some upward bias in this measure. It should be noted, however, that the unemployment rate used in the age of retirement equation was measured at the two-digit industry level and that most of the variation in unemployment in our sample is across industries, not over the business cycle. Inflation rates increased and decreased several times without any systematic pattern over the period that our panel aged. Evidence that these potential biases are not especially important comes from reestimating the equations including workers who were older than 60 at the start of the survey and who should, therefore, have been subject to different macroeconomic conditions at each age than the sample used for the main analysis. When this is 
done, the coefficient on unemployment is essentially unchanged while that on inflation is reduced by about $30 \%$.

With respect to unemployment and inflation at the start of the career, there is no apparent effect of unemployment on age of pension eligibility but some indication that higher inflation rates lead to earlier provision of pensions. This is a sensible finding if "monetary illusion” on the part of workers leads them to interpret higher nominal interest rates associated with higher inflation as an indication of greater ability to accumulate assets over their working life and, therefore, greater wealth at the time they want to retire.

The pattern of estimated coefficients on the job characteristics measures suggests that they play a role in the determination of retirement. In particular, the three characteristics that would seem to be easiest to observe at the time of hiring are all related to the age at which a worker first becomes eligible for a pension, results which generally support the theory that workers' ages of pension eligibility reflects the impact of job characteristics on their optimally desired retirement ages. Jobs that involve unpleasant conditions, greater exposure to hazards, and in which it is difficult to change duties all provide workers with earlier pensions. Conditional on their early eligibility for pensions, workers who are in jobs where it is difficult to change duties actually appear to retire at a later age. Perhaps this finding reflects an overly pessimistic view of the undesirability of this condition at the time workers enter their career jobs. The results regarding job flexibility and control are similar to those reported in Hurd and McGarry (1994), while those regarding physical conditions are similar to those in Gustman and Steinmeier (1986) and Holden (1988).

The final two columns of Table 3 report the results from the simultaneous ordered probit model where the age of pension eligibility is treated as endogenous. The key result is that the coefficient on the age of eligibility reverses sign (to an intuitively meaningless negative sign) and becomes statistically insignificant. Thus, it appears that it is important to treat pensions as endogenous in models of retirement behavior. This conclusion is further supported by the positive correlation between the error terms in the 
pension eligibility and age of retirement equations (although the t-statistic on this correlation falls shy of statistical significance).

Two factors that did not significantly impact age of pension eligibility do appear to be related to the age at which workers retire. These are the degree of responsibility for how their work is done (where more control over the workplace leads to significantly later retirement) and the effort workers expend on their job (which is negatively related to retirement age although just shy of conventional significance levels). We do not know why these factors are related to age of retirement but not to pension eligibility. One possibility is that they are more difficult to foresee when negotiating the terms of a pension plan than the factors we have found to be related to the age of eligibility. For example, both effort and degree of responsibility may be related to levels of success on the job (and the level to which a worker rises in an occupational hierarchy), an outcome that could not be predicted well at the time of initial contract setting. Thus, these factors in particular may exhibit a great deal of variation among workers covered by a common pension plan. No other results change substantially when the endogeneity of pensions is taken into account.

\section{C) Identification}

We turn now to issues of identification. The model consists of two interrelated ordered probit equations. Both equations are globally convex and the likelihood function for this system is highly nonlinear. As is widely established, nonlinear models of this type are globally identified by their functional form except in certain degenerative cases (see McManus, 1992, for a general proof, and Dansie, 1985, and Bunch and Kitamura, 1991, for a discussion of related models). Thus, the system we propose to estimate would be fully identified even if all variables were common to both equations (i.e. the $Y$ and $Z$ vectors in equations (1) and (2) were empty).

It is, or course, preferable to identify such systems through variables that can be excluded from each of the equations being estimated on theoretical grounds. This is not an easy task since the very nature of the decision process outlined argues that almost everything that is relevant for retirement decisions 
should be related to both the age of eligibility and the observed retirement age. Perhaps the strongest case can be made for economy-wide economic conditions. It is unlikely that an individual, when negotiating pension terms, can forecast macroeconomic conditions at the time he desires to retire. Thus, inflation and unemployment rates at the end of the working life should influence actual retirement decisions but not the ages of eligibility set decades earlier. Conversely, especially to the extent that they are taken as predictors of future conditions, macroeconomic conditions at the time of hire should affect desired retirement ages (and hence ages of eligibility) but will have been superseded by actual realizations by the time retirement age itself is determined. ${ }^{24}$

Given the paucity of exclusion restrictions available (as will be seen below, the excluded variables in the age of eligibility equation are not significant), we also investigated the fragility of the estimates. ${ }^{25} \mathrm{~A}$ number of findings give us confidence that identification of the current model based largely on functional form is not a problem. In particular: (1) the estimated parameters are insensitive to a wide range of starting values,$^{26}(2)$ similar estimates of the parameters are obtained when the model is estimated on randomly

${ }^{24}$ Other potential factors influencing desired retirement age, such as health and marital status at the time of hire, are not available in the RHS.

${ }^{25}$ Keane (1992) has pointed out for a related model that identification based on functional form may be tenuous or fragile in the absence of exclusion restrictions.

${ }^{26}$ Keene suggests that estimates that do not move very far from the starting values provided may be an indication of fragile identification. While many estimates from the simultaneous system reported below are close to the starting values provided from the single equations, this is a function of the quality of the starting values and not the fragility of the identification. Reestimating the system with widely different starting values results in these parameters moving extensively to approximately the values reported using precise starting values. 
chosen subsets of the data, ${ }^{27}$ (3) estimated Hessians are well behaved and far from singular, ${ }^{28}$ (4) we obtained reasonable values of standard errors including a low standard error for the cross equation correlation of error terms, similar standard errors no matter how derived (from analytic second derivatives (Newton), the covariance of analytic first derivatives (BHHH), or analytic first and second derivatives (Eiker-White)) and, in most cases, standard errors that are relatively close to those from the single equation.

\section{Conclusion}

We have examined a world in which both the age of pension eligibility and the age of retirement are determined by worker and job characteristics that influence productivity and reservation wages. Both workers and firms should anticipate an optimal age of retirement at the time of contract negotiation and, given long-term contract considerations, design a pension plan to induce retirement at this age. Thus, there will be a correlation between the age at which a worker retires and the age at which his pension enables him to receive benefits. This correlation, however, reflects the fact that both of these ages depend on common exogenous factors rather than one of them causing the other.

Empirical estimates support this basic framework. A conventional model where pensions are assumed to be exogenous suggests that delaying the age of pension eligibility would have a significant effect in delaying the age at which the worker retires. Once the endogeneity of eligibility age is taken into account, however, there is a substantially reduced (and statistically insignificant) role for pensions themselves as a determinant of retirement. Indeed, they retain no additional explanatory power beyond that provided by worker and job characteristics, as well as the macroeconomic environment. Thus, the

\footnotetext{
${ }^{27}$ We are grateful to Arthur Lewbel for suggesting this test of the identification of the model. We reestimated the model a number of times, each using a different randomly drawn subsample of the data. In every case the estimated coefficient from the simultaneous system was lower than that when age of eligibility was treated as exogenous, and in no case was the estimated coefficient from any one subsample statistically different from that from any other of the subsamples.

${ }^{28}$ See Davidson and MacKinnon (1993). Situations where identification is fragile typically require adjustments such as suggested by Marquadt (1963) to obtain a sensible direction vector.
} 
results support our intuition that truly exogenous alteration of pension characteristics is likely to result in offsetting changes in private saving rather than major changes in retirement behavior.

These results should be regarded as suggestive. Information on job characteristics has been added from sources other than the Retirement History Survey and pertains to a worker's occupation in general, not his specific job, with a resulting introduction of measurement errors. In addition, relatively little is known about worker characteristics such as health and marital status at the start of career jobs. Repeated analysis of the type undertaken here using a richer data set such as the Health and Retirement Survey, when future waves capture widespread retirement in the sample, is necessary before weight is placed on estimated responses to changes in pension systems derived from research that has treated the characteristics of pension plans as exogenous. 


\section{REFERENCES}

Bankers Trust Company. Corporate Pension Plan Study. New York, 1980.

Becker, Gary S. "Investment in Human Capital: A Theoretical Analysis." Journal of Political Economy 70 (1962): 9-49.

Blekesaune, Morten and Solem, Per Erik. "Working Conditions and Early Retirement.” Research on Aging 27 (2005): 3-30.

Blau, David M. “Labor Force Dynamics of Older Men,” Econometrica 62 (1994): 117-56.

Blundell, Richard, Meghir, Costas and Smith, Sarah. "Pension Incentives and the Pattern of Early Retirement.” Economic Journal 112 (2002) C153-C170.

Boskin, Michael J. and Hurd, Michael D. "The Effect of Social Security Benefits on Early Retirement." Journal of Public Economics 10 (1978): 361-77.

Brown, Charles. “Early Retirement Windows: Windows of Opportunity? Defenestrations?” (1996) photocopy, University of Michigan.

Bunch, D. S. and Kitamura, R. "Multinomial Probit Estimation Revisited: Testing Estimable Model Specifications, Maximum Likelihood Algorithms, and Probit Integral Approximations for Trinomial Models of Household Car Ownership.” Working paper, University of California at Davis, Graduate School of Management, 1991.

Burkhauser, Richard V. "The Pension Acceptance Decision of Older Workers." Journal of Human Resources 14 (1979): 435-52.

, and Quinn, Joseph F. "Is Mandatory Retirement Overrated? Evidence from the 1970s." Journal of Human Resources 18 (1983): 337-58.

Burtless, Gary, and Moffitt, Robert A. "Effect of Social Security Benefits on Labor Supply." In Retirement and Economic Behavior. Henry J. Aaron and Gary Burtless (eds.). Washington, D.C.: Brookings Institution, 1984.

Butler, J. S. And Chatterjee, Patrali. "Tests of the Specification of Univariate and Bivariate Ordered Probit.” Review of Economics and Statistics. 79 (1997): 343-347.

Chan, Sewin and Stevens, Ann Huff. "Do Changes in Pension Incentives Affect Retirement? - A Longitudinal Study of Subjective Retirement Expectations.” Journal of Public Economics. 88 (2004) 1307-1333.

Chirikos, Thomas N., and Nestel, Gilbert. "Occupational Differences in the Ability of Men to Delay Retirement.” Journal of Human Resources. 26 (1991) 1-26.

Clark, Robert L., Gohmann, Stephen F., and McDermed, Ann A. "Declining Use of Defined Benefit Pension Plans: Is Federal Regulation the Reason?" Department of Economics Working Paper. Raleigh, NC: North Carolina State University, 1988.

Coile, Courtney and Gruber, Jonathan “Social Security and Retirement.” NBER Working Paper 7830. Cambridge: National Bureau of Economic Research, 2000.

Dansie B. "Parameter Estimability in the Multinomial Probit Model.” Transportation Research 19 (1985): 526-528.

Davidson, Russell and James G. MacKinnon. Estimation and Inference in Econometrics, Oxford: Oxford University Press, 1993. 
Derriennic, Francis, Saurel-Cubizolles, Marie-Josephe, and Montfort, Christine. "Santé, Conditions de Travail et Cessation d'activité des Salaries Agés.” Travail et Emploi 0 (2003) 37-53.

Doeringer, Peter B. and Terkla, D. G. "Jobs for Older Workers: Is the Nonbureaucratic Firm the Answer." Industrial Relations Research Association: Proceedings of the Forty-First Annual Meeting, December 1988. Madison: IRRA, 1989.

Fields, Gary. S. and Mitchell, Olivia S. "The Effects of Pensions and Earnings on Retirement: A Review Essay." In Research in Labor Economics, edited by R. Ehrenberg. New Haven: JAI Press, 1982.

- Retirement, Pensions, and Social Security. Cambridge: MIT Press, 1984.

Filer, Randall K. "Occupational Segregation, Compensating Differentials and Comparable Worth." In Pay Equity: Empirical Inquiries. Robert Michael and Heidi Hartmann (eds.). National Academy of Sciences/National Research Council, Washington: National Academy Press, 1989.

, and Petri, Peter A. "A Job-Characteristics Theory of Retirement." Review of Economics and Statistics 70 (1988): 123-9.

and Honig, Marjorie “Endogenous Pensions and Retirement Behavior.” New York: Hunter College Working Paper 410. May 2005.

Greene, William H. Econometric Analysis, Second Edition. New York: Macmillan Publishing, 1993.

Gustman, Alan A., and Steinmeier, Thomas L. "Partial Retirement and the Analysis of Retirement Behavior." Industrial and Labor Relations Review 37 (1984): 403-15.

. "The 1983 Social Security Reforms and Labor Supply Adjustments of Older Individuals in the Long Run." Journal of Labor Economics 3 (1985): 237-53.

. "A Structural Retirement Model." Econometrica 54 (1986): 555-84.

. "An Analysis of Pension Benefit Formulas, Pension Wealth and Incentives from Pensions." In Research in Labor Economics. Ronald J. Ehrenberg (ed.). Greenwich, Ct: JAI Press, 1989.

Gustman, Alan A., Mitchell, Olivia S., and Steinmeier, Thomas L. "The Role of Pensions in the Labor Market." Industrial and Labor Relations Review 47 (1994): 417-438.

Hashimoto, Masanori. "Firm-specific Human Capital as a Shared Investment," American Economic Review 71 (1981): 475-482.

, and B. T. Yu. “Specific Capital, Employment Contracts and Wage Rigidity.” Bell Journal of Economics 11 (1980): 536-549.

Hanoch, Giora, and Honig, Marjorie. "Retirement, Wages, and Labor Supply of the Elderly." Journal of Labor Economics 1 (1983): 131-51.

Hausman, Jerry A. and Wise, David A. "Social Security, Health Status, and Retirement." In Pensions, Labor, and Individual Choice. David A. Wise (ed.). Chicago: University of Chicago Press, 1985.

Hayward, Mark D., Grady, William R., Hardy, Melissa, and Sommers, David. "Occupational Influences on Retirement, Disability, and Death." Demography 26 (1989): 393-409.

Hayward, Mark D., Friedman, Samantha, and Chen, Hsinmu. “Career Trajectories and Older Men’s Retirement.” Journals of Gerontology, Series B: Psychological Sciences and Social Sciences. 53 (1998) 91-103. 
Hirsch, Barry T., Macpherson, David A., and Hardy, Melissa A. "Occupational Age Structure and Access for Older Workers.” Industrial and Labor Relations Review. 53 (2000): 401-418.

Holden, Karen C. "Physically Demanding Occupations, Health, and Work After Retirement: Findings from the New Beneficiary Survey." Social Security Bulletin 51 (1988): 3-15.

Honig, Marjorie, and Hanoch, Giora. "Estimation of Labor Supply and Retirement Behavior." Paper prepared for Brookings Institution Conference on Aging and Retirement, Washington, D.C., January 1981.

Honig, Marjorie, and Reimers, Cordelia. "Retirement, Re-entry, and Part-Time Work." Eastern Economic Journal 13 (1987): 361-71.

. "Is It Worth Eliminating the Retirement Test?" American Economic Review 79 ( 1989): 103-7.

Hurd, Michael D., and Boskin, Michael J. "The Effect of Social Security on Retirement in the Early 1970s." Quarterly Journal of Economics 99 (1984): 767-90.

Hurd, Michael D., and McGarry, Kathleen. "The Relationship between Job Characteristics and Retirement." NBER Working Paper No. 4462. Cambridge, MA: National Bureau of Economic Research, 1994.

Ippolito, Richard A. "Toward Explaining Earlier Retirement After 1970," Industrial and Labor Relations Review 43 (1990): 556-69.

Johnson, Richard W. “Trends in Job Demands Among Older Workers, 1992-2002.” Monthly Labor Review 127 (2004) 48-56.

Keane, Michael P. “A Note on Indentification in the Multinomial Probit Model.” Journal of Business and Economic Statistics 10 (1992): 193-200.

Kotlikoff, Laurence J., and Smith, Daniel E. Pensions in the American Economy. Chicago: University of Chicago Press, 1983.

Kotlikoff, Laurence J., and Wise, David A. "The Incentive Effects of Private Pensions Plans." In Issues in Pension Economics. Avi Bodie, John Shoven and David A. Wise (eds.). Chicago: The University of Chicago Press, 1987.

Lazear, Edward P. "Why Is There Mandatory Retirement?" Journal of Political Economy 87 (1979): 1261-84.

. "Retirement from the Labor Force." In Handbook of Labor Economics, Volume l. Orley C. Ashenfelter and Richard Layard (eds.). Amsterdam: North-Holland, 1986.

Lee, L. F. "A Bivariate Logit Model." Center for Econometrics and Decision Sciences Working Paper, College of Business Administration, University of Florida, 1982.

Lumsdaine, Robin, Stock, James, and Wise, David A. "Pension Plan Provisions and Retirement: Men and Women, Medicare and Models." NBER Working Paper No. 4201. Cambridge, MA: National Bureau of Economic Research, 1992.

Marquadt, D. “An Algorithm for the Estimation of Non-Linear Parameters.” Society for Industrial and Applied Mathematics Journal 11 (1963): 431-441.

McManus, Douglas A. “How Common is Identification in Parametric Models?” Journal of Econometrics $53(1992): 5-23$.

Moon, Choon-Geol, and Stotsky, Janet. "Testing the Differences Between the Determinants of Moody's and Standard \& Poor's Ratings." Journal of Applied Econometrics 8 (1993): 51-69. 
Mortensen, Dale. “Specific Capital and Labor Turnover.” Bell Journal of Economics 9 (1978): 572-586.

Mutschler, Phyllis H. "How Golden a Handshake? Reactions to Early Retirement Incentive Plans.” Compensation and Benefits Management 2 (1986): 277-283.

OECD, "Private Pensions in OECD Countries: The United Kingdom,” Paris: OECD Labour Market and Social Policy Occasional Papers No 21, 1997.

Poon, W. Y., Lee, S.-Y., and Bentler, P. M. "Simultaneous Analysis of Multivariate Polytomous Variates in Several Groups." ASA - 1987 Proceedings of the Social Statistics Section, American Statistical Association: 564-69.

Quinn, Joseph F. "Microeconomic Determinants of Early Retirement: A Cross-Sectional View of White Married Men." Journal of Human Resources 12 (1977): 329-47.

. "Job Characteristics and Early Retirement." Industrial Relations 17 (1978): 315-23.

, Burkhauser, Richard V. and Myers, Daniel A. Passing the Torch: The Influence of Economic Incentives on Work and Retirement. Kalamazoo: W.E. Upjohn Institute, 1990.

Reimers, Cordelia. "The Timing of Retirement of American Men," unpublished Ph.D. Dissertation, Columbia University, 1977.

, and Honig, Marjorie. "The Perceived Budget Constraint under Social Security: Evidence from Reentry Behavior." Journal of Labor Economics 11 (1993): 184-204.

. "Responses to Social Security by Men and Women: Myopic and Far-sighted Behavior." Journal of Human Resources 31 (1996): 359-382.

Salop, Joanne, and Salop, Steven. "Self-Selection and Turnover in the Labor Market." Quarterly Journal of Economics 90 (1975): 619-627.

Siddiqui, Sikandar. “The Pension Incentive to Retire: Empirical Evidence from West Germany.” Journal of Population Economics 10 (1997): 463-468.

Solem, Per Erik and Mykletun, Reidar. "Work Environment and Early Exit from Work.” In Work After 45? Å Kilbom, P. Westerholm, I. Hallsten and B. Furåker. Solna, Sweden: National Institute for Working Life, 1997.

Stock, James H., and Wise, David A. "The Pension Inducement to Retire: An Option Value Analysis." In Issues in the Economics of Aging. David A. Wise (ed.). Chicago: University of Chicago Press, 1990.

“Pensions, The Option Value of Work, and Retirement,” Econometrica 58 (1990): 1151-80.

Thio, Vincent, and Woittiez, Isolde. "Wages and Early Retirement: An Hedonic Price Approach.” Working Paper, Centre for Economic Research on Retirement and Ageing, Leiden University, The Netherlands, 1996.

Uesaka, H. "Analysis of Bivariate Ordered Categorical Data by Normal Models," Behaviormetrika, 19 (1986): 87-101.

Woodland, A.D. “Determinants of the Labour Force Status of the Aged,” Economic Record 63 (1987): 97-114.

Yates, Dale E., Folts, W. Edward, and Knapp, James. “Older Workers’ Adaptation to a Changing Workplace: Employment Issues for the $21^{\text {st }}$ Century.” Educational Gerontology. 26 (2000): 565582. 
Table 1

\section{Average Age of Retirement of Men in Selected Occupations}

\begin{tabular}{|c|c|c|c|c|}
\hline Aircraft Mechanics & 58.6 & Photoengravers & & 65.0 \\
\hline Explosives Workers & 59.2 & Painters & & 65.1 \\
\hline Air Traffic Controllers & 59.2 & Secretaries & & 65.2 \\
\hline Actors & 59.6 & Bailiffs & 65.2 & \\
\hline Computer Analysts & 59.9 & Civil Engineers & & 65.4 \\
\hline Pilots & 59.9 & Real Estate Agents & & 65.6 \\
\hline Agricultural Scientists & 60.2 & Musicians & & 65.7 \\
\hline Rolling Machine Operators & 60.2 & Librarians & & 66.0 \\
\hline Economists & 60.3 & Stock Brokers & & 66.2 \\
\hline Police Officers \& Detectives & 60.3 & Barbers & & 66.5 \\
\hline Computer Operators & 60.5 & Watch Repairers & & 66.7 \\
\hline Shoe Machine Operators & 60.9 & Elevator Operators & & 66.8 \\
\hline Materials Engineers & 61.1 & Surveyors & & 66.9 \\
\hline Sailors and Deckhands & 61.2 & Farm Workers & & 67.0 \\
\hline Railroad Conductors & 61.2 & Parking Lot Attendants & & 67.3 \\
\hline Telephone Line Installers & 61.3 & Proofreaders & & 67.6 \\
\hline Mail Carriers & 61.5 & Clergy & & 67.9 \\
\hline Forestry Workers & 61.5 & Shoe Salespersons & & 68.0 \\
\hline Concrete Finishers & 61.6 & Atmospheric Scientists & & 68.1 \\
\hline Structural Metal Workers & 61.7 & Motion Picture Projectionists & & 68.6 \\
\hline Sales Engineers & 61.9 & Bridge Lighthouse Attendants & & 69.0 \\
\hline Typists & 62.3 & Child Care Workers & & 69.0 \\
\hline Fishers & 62.6 & Lawyers & & 69.1 \\
\hline Elementary School Teachers & 62.7 & Billing Clerks & & 69.3 \\
\hline Automobile Mechanics & 62.8 & Physicians & & 69.3 \\
\hline Machinists & 62.9 & Paperhangers & & 69.3 \\
\hline Air Conditioning Mechanics & 63.2 & Purchasing Agents & & 69.8 \\
\hline Automobile Salespersons & 63.4 & Authors & & 70.6 \\
\hline Pest Control Personnel & 63.7 & Judges & & 70.8 \\
\hline Financial Managers & 63.8 & Crossing Guards & & 71.0 \\
\hline
\end{tabular}


Carpenters

Furniture Salespersons

Waiters and Waitresses

Architects

Insurance Agents

Accountants
63.9

63.9

64.1

64.3

64.7

64.7

Household Appliance Repairers 64.9

Source: Calculated from 1980 Census Public Use Microdata Tapes. Age of retirement was calculated from current age and year last worked for all those who were currently over 50, not in the labor force, and not disabled. 
Table 2

Distributions of Age of First Pension Eligibility and Age of Retirement

\begin{tabular}{|l|c|c|c|c|c|c|}
\hline \multirow{2}{*}{$\begin{array}{l}\text { Actual Age of } \\
\text { Retirement }\end{array}$} & \multicolumn{6}{|c|}{ Age First Eligible for Private Pension } \\
\cline { 2 - 7 } & $<\mathbf{6 2}$ & $\mathbf{6 2}$ & $\mathbf{6 3 - 6 4}$ & $\mathbf{6 5}$ & $>\mathbf{6 5}$ & Total \\
\hline$<\mathbf{6 2}$ & 10 & 30 & 0 & 18 & 0 & 58 \\
\hline $\mathbf{6 2}$ & 25 & 59 & 2 & 28 & 2 & 116 \\
\hline $\mathbf{6 3 - 6 4}$ & 9 & 50 & 7 & 39 & 2 & 107 \\
\hline $\mathbf{6 5}$ & 8 & 58 & 6 & 67 & 2 & 141 \\
\hline$>\mathbf{6 5}$ & 2 & 13 & 1 & 13 & 2 & 31 \\
\hline \hline Total & 54 & 210 & 16 & 165 & 8 & 453 \\
\hline
\end{tabular}


Table 3

Determinants of Ages of Pension Eligibility and Retirement Including Job Characteristics (Standard Errors in Parentheses)

\begin{tabular}{|c|c|c|c|c|}
\hline & \multicolumn{2}{|c|}{ Independent Equations $^{\mathrm{a}}$} & \multicolumn{2}{|c|}{ Simultaneous System ${ }^{\mathrm{b}}$} \\
\hline & $\begin{array}{c}\text { Age of } \\
\text { Eligibility }\end{array}$ & $\begin{array}{c}\text { Age of } \\
\text { Retirement }\end{array}$ & $\begin{array}{l}\text { Age of } \\
\text { Eligibility }\end{array}$ & $\begin{array}{c}\text { Age of } \\
\text { Retirement }\end{array}$ \\
\hline \multirow[t]{2}{*}{ Age of Eligibility } & & $0.081 * *$ & & -.039 \\
\hline & & $(.032)$ & & $(.113)$ \\
\hline \multirow[t]{2}{*}{ Government Employee } & -0.251 & 0.228 & -0.251 & 0.178 \\
\hline & $(.179)$ & $(.175)$ & $(.188)$ & $(.185)$ \\
\hline \multirow[t]{2}{*}{ Education } & -0.0027 & 0.023 & 0.0032 & 0.022 \\
\hline & $(.024)$ & $(.021)$ & $(.024)$ & $(.022)$ \\
\hline \multirow[t]{2}{*}{ Permanent Income ('000s) } & -0.0051 & -0.00012 & -0.0050 & -0.00087 \\
\hline & $(.0045)$ & $(.0042)$ & $(.0048)$ & $(.0043)$ \\
\hline \multirow{2}{*}{$\begin{array}{l}\text { Age at Start of Career Job } \\
\text { (in months) }\end{array}$} & $0.0016 * * *$ & 0.0003 & $0.0016^{* * *}$ & 0.00051 \\
\hline & $(.0005)$ & $(.0004)$ & $(.00052)$ & $(.00046)$ \\
\hline \multirow{2}{*}{$\begin{array}{l}\text { Health Limitation at End of } \\
\text { Career Job }\end{array}$} & 0.046 & $-0.264^{* *}$ & 0.043 & $-0.252 * *$ \\
\hline & $(.125)$ & $(.114)$ & $(.128)$ & $(.117)$ \\
\hline \multirow{2}{*}{$\begin{array}{l}\text { Inflation at Start of Career } \\
\text { Job }\end{array}$} & -1.15 & & -1.46 & \\
\hline & $(1.41)$ & & $(1.45)$ & \\
\hline \multirow{2}{*}{$\begin{array}{l}\text { Unemployment at Start of } \\
\text { Career Job }\end{array}$} & 0.410 & & 0.503 & \\
\hline & $(.923)$ & & $(.925)$ & \\
\hline \multirow{2}{*}{$\begin{array}{l}\text { Inflation at End of Career } \\
\text { Job }\end{array}$} & & $0.190 * * *$ & & $0.185^{* * *}$ \\
\hline & & $(.025)$ & & $(.026)$ \\
\hline \multirow{2}{*}{$\begin{array}{l}\text { Unemployment at End of } \\
\text { Career Job }\end{array}$} & & $0.100 * * *$ & & $0.096^{* * *}$ \\
\hline & & $(.019)$ & & $(.020)$ \\
\hline \multirow{2}{*}{$\begin{array}{l}\text { Still Married at End of } \\
\text { Career Job }\end{array}$} & & -0.200 & & -0.172 \\
\hline & & $(.283)$ & & $(.286)$ \\
\hline
\end{tabular}




\begin{tabular}{|c|c|c|c|c|}
\hline & \multicolumn{2}{|c|}{ Independent Equations $^{\mathrm{a}}$} & \multicolumn{2}{|c|}{ Simultaneous System ${ }^{\mathrm{b}}$} \\
\hline & $\begin{array}{l}\text { Age of } \\
\text { Eligibility }\end{array}$ & $\begin{array}{c}\text { Age of } \\
\text { Retirement }\end{array}$ & $\begin{array}{l}\text { Age of } \\
\text { Eligibility }\end{array}$ & $\begin{array}{c}\text { Age of } \\
\text { Retirement }\end{array}$ \\
\hline Resident of Warm Region & & $\begin{array}{c}0.387 * * * \\
(.109)\end{array}$ & & $\begin{array}{c}0.384 * * * \\
(.109)\end{array}$ \\
\hline $\begin{array}{l}\text { Exposure to Hazards on the } \\
\text { Job }\end{array}$ & $\begin{array}{l}-0.461 \\
(.330)\end{array}$ & $\begin{array}{l}-0.106 \\
(.399)\end{array}$ & $\begin{array}{l}-0.466 \\
(.340)\end{array}$ & $\begin{array}{l}-0.167 \\
(.408)\end{array}$ \\
\hline $\begin{array}{l}\text { Unpleasant Working } \\
\text { Conditions }\end{array}$ & $\begin{array}{l}-0.507 \\
(.391)\end{array}$ & $\begin{array}{l}0.025 \\
(.384)\end{array}$ & $\begin{array}{l}-0.502 \\
(.401)\end{array}$ & $\begin{array}{l}-0.043 \\
(.385)\end{array}$ \\
\hline $\begin{array}{l}\text { Difficulty of Changing } \\
\text { Duties }\end{array}$ & $\begin{array}{c}-0.487 * * \\
(.214)\end{array}$ & $\begin{array}{l}0.363^{*} \\
(.210)\end{array}$ & $\begin{array}{c}-0.485^{* *} \\
(.217)\end{array}$ & $\begin{array}{l}0.280 \\
(.228)\end{array}$ \\
\hline $\begin{array}{l}\text { Responsibility for How } \\
\text { Things Get Done }\end{array}$ & $\begin{array}{l}-0.095 \\
(.209)\end{array}$ & $\begin{array}{l}0.420^{*} \\
(.220)\end{array}$ & $\begin{array}{l}-0.098 \\
(.215)\end{array}$ & $\begin{array}{l}0.423^{*} \\
(.229)\end{array}$ \\
\hline Effort & $\begin{array}{l}0.096 \\
(.354)\end{array}$ & $\begin{array}{l}-0.482 \\
(.370)\end{array}$ & $\begin{array}{l}0.096 \\
(.364)\end{array}$ & $\begin{array}{l}-0.425 \\
(.388)\end{array}$ \\
\hline First Threshold & $\begin{array}{c}1.445^{* * *} \\
(.088)\end{array}$ & $\begin{array}{c}1.064^{* * *} \\
(.088)\end{array}$ & $\begin{array}{c}1.448 * * * \\
(.090)\end{array}$ & $\begin{array}{c}1.048 * * * \\
(.094)\end{array}$ \\
\hline Second Threshold & $\begin{array}{c}1.504 * * * \\
(.089)\end{array}$ & $\begin{array}{c}1.501^{* * *} \\
(.101)\end{array}$ & $\begin{array}{c}1.508 * * * \\
(.091)\end{array}$ & $\begin{array}{c}1.477 * * * \\
(.113)\end{array}$ \\
\hline Third Threshold & $\begin{array}{c}1.541^{* * * *} \\
(.090)\end{array}$ & $\begin{array}{c}1.909 * * * \\
(.110)\end{array}$ & $\begin{array}{c}1.544^{* * *} \\
(.091)\end{array}$ & $\begin{array}{c}1.877 * * * \\
(.128)\end{array}$ \\
\hline Fourth Threshold & $\begin{array}{c}3.422 * * * \\
(.183)\end{array}$ & $\begin{array}{c}3.317 * * * \\
(.127)\end{array}$ & $\begin{array}{c}3.417 * * * \\
(.190)\end{array}$ & $\begin{array}{c}3.260 * * * \\
(.170)\end{array}$ \\
\hline Constant & $\begin{array}{l}2.647 * \\
(1.47)\end{array}$ & $\begin{array}{l}-1.605 \\
(1.64)\end{array}$ & $\begin{array}{l}2.640 * \\
(1.50)\end{array}$ & $\begin{array}{l}-1.310 \\
(1.71)\end{array}$ \\
\hline Correlation of Error Terms & & & & \\
\hline
\end{tabular}

${ }^{a}$ Independent Ordered Probit Estimates. Age groups equal <62, 62, 63, 64, 65, >65.

bBivariate Ordered Probit Estimates. Age groups equal <62, 62, 63, 64, 65, $>65$.

*Statistically significant at the .10 level; **at the .05 level; ***at the .01 level. 
Appendix Table A-1

Employment Status in 1969

White Males Aged 58-63

STATUS

Total

Not employed in 1969

Employed - Job began after age 55

Employed - Job began before age 55:

Self-reported retired

Still on career job in 1969
Number

2541

365

14.4

506

19.9

18

0.7

1652

$\underline{65.0}$

100.0

Of those on career job in 1969:

Hrs/wk always $<30$

Transition to hrs/wk < 30, same employer

Transition directly to new employer

No transition observed

Retired 1969 to 1979

Of those observed to retire 1969-1979:

Covered by employer pension
3

53

96

247

1253

913

72.9

Of those covered by pension:

Industry and occupation reported

Of those with complete data:

Ages 58-60 in 1969 


\section{CESifo Working Paper Series}

(for full list see www.cesifo-group.de)

1485 Carsten Hefeker, Uncertainty, Wage Setting and Decision Making in a Monetary Union, June 2005

1486 Ondřej Schneider and Jan Zápal, Fiscal Policy in New EU Member States - Go East, Prudent Man!, June 2005

1487 Christian Schultz, Virtual Capacity and Competition, June 2005

1488 Yvan Lengwiler and Elmar Wolfstetter, Bid Rigging - An Analysis of Corruption in Auctions, June 2005

1489 Johannes Becker and Clemens Fuest, Does Germany Collect Revenue from Taxing Capital Income?, June 2005

1490 Axel Dreher and Panu Poutvaara, Student Flows and Migration: An Empirical Analysis, June 2005

1491 Bernd Huber and Marco Runkel, Interregional Redistribution and Budget Institutions under Asymmetric Information, June 2005

1492 Guido Tabellini, Culture and Institutions: Economic Development in the Regions of Europe, July 2005

1493 Kurt R. Brekke and Michael Kuhn, Direct to Consumer Advertising in Pharmaceutical Markets, July 2005

1494 Martín Gonzalez-Eiras and Dirk Niepelt, Sustaining Social Security, July 2005

1495 Alfons J. Weichenrieder, (Why) Do we need Corporate Taxation?, July 2005

1496 Paolo M. Panteghini, S-Based Taxation under Default Risk, July 2005

1497 Panos Hatzipanayotou and Michael S. Michael, Migration, Tied Foreign Aid and the Welfare State, July 2005

1498 Agata Antkiewicz and John Whalley, BRICSAM and the Non-WTO, July 2005

1499 Petr Hedbávný, Ondřej Schneider and Jan Zápal, A Fiscal Rule that has Teeth: A Suggestion for a 'Fiscal Sustainability Council' underpinned by the Financial Markets, July 2005

1500 J. Atsu Amegashie and Marco Runkel, Sabotaging Potential Rivals, July 2005 
1501 Heikki Oksanen, Actuarial Neutrality across Generations Applied to Public Pensions under Population Ageing: Effects on Government Finances and National Saving, July 2005

1502 Xenia Matschke, Costly Revenue-Raising and the Case for Favoring Import-Competing Industries, July 2005

1503 Horst Raff and Nicolas Schmitt, Why Parallel Trade may Raise Producers Profits, July 2005

1504 Alberto Bisin and Piero Gottardi, Efficient Competitive Equilibria with Adverse Selection, July 2005

1505 Peter A. Zadrozny, Necessary and Sufficient Restrictions for Existence of a Unique Fourth Moment of a Univariate GARCH(p,q) Process, July 2005

1506 Rainer Niemann and Corinna Treisch, Group Taxation, Asymmetric Taxation and Cross-Border Investment Incentives in Austria, July 2005

1507 Thomas Christiaans, Thomas Eichner and Ruediger Pethig, Optimal Pest Control in Agriculture, July 2005

1508 Biswa N. Bhattacharyay and Prabir De, Promotion of Trade and Investments between China and India: The Case of Southwest China and East and Northeast India, July 2005

1509 Jean Hindriks and Ben Lockwood, Decentralization and Electoral Accountability: Incentives, Separation, and Voter Welfare, July 2005

1510 Michelle R. Garfinkel, Stergios Skaperdas and Constantinos Syropoulos, Globalization and Domestic Conflict, July 2005

1511 Jesús Crespo-Cuaresma, Balázs Égert and Ronald MacDonald, Non-Linear Exchange Rate Dynamics in Target Zones: A Bumpy Road towards a Honeymoon - Some Evidence from the ERM, ERM2 and Selected New EU Member States, July 2005

1512 David S. Evans and Michael Salinger, Curing Sinus Headaches and Tying Law: An Empirical Analysis of Bundling Decongestants and Pain Relievers, August 2005

1513 Christian Keuschnigg and Martin D. Dietz, A Growth Oriented Dual Income Tax, July 2005

1514 Fahad Khalil, David Martimort and Bruno Parigi, Monitoring a Common Agent: Implications for Financial Contracting, August 2005

1515 Volker Grossmann and Panu Poutvaara, Pareto-Improving Bequest Taxation, August 2005

1516 Lars P. Feld and Emmanuelle Reulier, Strategic Tax Competition in Switzerland: Evidence from a Panel of the Swiss Cantons, August 2005 
1517 Kira Boerner and Silke Uebelmesser, Migration and the Welfare State: The Economic Power of the Non-Voter?, August 2005

1518 Gabriela Schütz, Heinrich W. Ursprung and Ludger Wößmann, Education Policy and Equality of Opportunity, August 2005

1519 David S. Evans and Michael A. Salinger, Curing Sinus Headaches and Tying Law: An Empirical Analysis of Bundling Decongestants and Pain Relievers, August 2005

1520 Michel Beine, Paul De Grauwe and Marianna Grimaldi, The Impact of FX Central Bank Intervention in a Noise Trading Framework, August 2005

1521 Volker Meier and Matthias Wrede, Pension, Fertility, and Education, August 2005

1522 Saku Aura and Thomas Davidoff, Optimal Commodity Taxation when Land and Structures must be Taxed at the Same Rate, August 2005

1523 Andreas Haufler and Søren Bo Nielsen, Merger Policy to Promote 'Global Players'? A Simple Model, August 2005

1524 Frederick van der Ploeg, The Making of Cultural Policy: A European Perspective, August 2005

1525 Alexander Kemnitz, Can Immigrant Employment Alleviate the Demographic Burden? The Role of Union Centralization, August 2005

1526 Baoline Chen and Peter A. Zadrozny, Estimated U.S. Manufacturing Production Capital and Technology Based on an Estimated Dynamic Economic Model, August 2005

1527 Marcel Gérard, Multijurisdictional Firms and Governments' Strategies under Alternative Tax Designs, August 2005

1528 Joerg Breitscheidel and Hans Gersbach, Self-Financing Environmental Mechanisms, August 2005

1529 Giorgio Fazio, Ronald MacDonald and Jacques Mélitz, Trade Costs, Trade Balances and Current Accounts: An Application of Gravity to Multilateral Trade, August 2005

1530 Thomas Christiaans, Thomas Eichner and Ruediger Pethig, A Micro-Level 'Consumer Approach' to Species Population Dynamics, August 2005

1531 Samuel Hanson, M. Hashem Pesaran and Til Schuermann, Firm Heterogeneity and Credit Risk Diversification, August 2005

1532 Mark Mink and Jakob de Haan, Has the Stability and Growth Pact Impeded Political Budget Cycles in the European Union?, September 2005

1533 Roberta Colavecchio, Declan Curran and Michael Funke, Drifting Together or Falling Apart? The Empirics of Regional Economic Growth in Post-Unification Germany, September 2005 
1534 Kai A. Konrad and Stergios Skaperdas, Succession Rules and Leadership Rents, September 2005

1535 Robert Dur and Amihai Glazer, The Desire for Impact, September 2005

1536 Wolfgang Buchholz and Wolfgang Peters, Justifying the Lindahl Solution as an Outcome of Fair Cooperation, September 2005

1537 Pieter A. Gautier, Coen N. Teulings and Aico van Vuuren, On-the-Job Search and Sorting, September 2005

1538 Leif Danziger, Output Effects of Inflation with Fixed Price- and Quantity-Adjustment Costs, September 2005

1539 Gerhard Glomm, Juergen Jung, Changmin Lee and Chung Tran, Public Pensions and Capital Accumulation: The Case of Brazil, September 2005

1540 Yvonne Adema, Lex Meijdam and Harrie A. A. Verbon, The International Spillover Effects of Pension Reform, September 2005

1541 Richard Disney, Household Saving Rates and the Design of Social Security Programmes: Evidence from a Country Panel, September 2005

1542 David Dorn and Alfonso Sousa-Poza, Early Retirement: Free Choice or Forced Decision?, September 2005

1543 Clara Graziano and Annalisa Luporini, Ownership Concentration, Monitoring and Optimal Board Structure, September 2005

1544 Panu Poutvaara, Social Security Incentives, Human Capital Investment and Mobility of Labor, September 2005

1545 Kjell Erik Lommerud, Frode Meland and Odd Rune Straume, Can Deunionization Lead to International Outsourcing?, September 2005

1546 Robert Inklaar, Richard Jong-A-Pin and Jakob de Haan, Trade and Business Cycle Synchronization in OECD Countries: A Re-examination, September 2005

1547 Randall K. Filer and Marjorie Honig, Endogenous Pensions and Retirement Behavior, September 2005 